\title{
Enhancing Freedom to Operate for Plant Breeders and Farmers through Open Source Plant Breeding
}

\author{
Claire H. Luby, ${ }^{\star}$ Jack Kloppenburg, Thomas E. Michaels, and Irwin L. Goldman
}

\begin{abstract}
The Open Source Seed Initiative (OSSI) (www. osseeds.org) seeks to address the dramatic transition over the past $100 \mathrm{yr}$ in how plant germplasm is distributed, developed, and released: from a freely available resource primarily located in the public sector to proprietary structures managed largely by the private sector. OSSI was developed by a group of plant breeders, farmers, seed companies, nonprofit organizations, and policymakers with the goal of promoting and maintaining open access to plant genetic resources worldwide. OSSI seeks to provide an alternative to pervasive intellectual property rights agreements that restrict freedom to use plant germplasm through the development and promulgation of a Pledge which is intended both to raise awareness of these issues and to ensure that germplasm can be freely exchanged now and into the future. In this paper we discuss the historical forces and trends that have led to various types of biological and intellectual property protections and how this has potentially limited plant breeders' "freedom to operate" and farmers' sovereignty over seed. We then discuss how OSSI is providing an alternative to increasingly restrictive intellectual property rights for plants and working to maintain open access to plant germplasm.
\end{abstract}

C.H. Luby and I.L. Goldman, Dep. of Horticulture, Univ. of WisconsinMadison, 1575 Linden Dr., Madison, WI 53706; J. Kloppenburg, Dep. of Community and Environmental Sociology, Univ. of WisconsinMadison, 1450 Linden Dr., Madison, WI 53706; T.E. Michaels, Dep. of Horticultural Science, Univ. of Minnesota, 456 Alderman Hall, Saint Paul, MN 55108. Received 16 Oct. 2014. Accepted 17 Dec. 2014. ^Corresponding author (cluby@wisc.edu).

Abbreviations: FOSS, free and open source software; IPR, intellectual property rights; MTA, material transfer agreement; NPGS, National Plant Germplasm System; OSSI, Open Source Seed Initiative; PVP, Plant Variety Protection; PVPA, Plant Variety Protection Act; UPOV, Union for the Protection of New Varieties of Plants.

$\mathrm{O}$ N 17 Apr. 2014, in solidarity with La Via Campesina's International Day of Struggle in Defense of Peasants' and Farmers' Seeds, the Open Source Seed Initiative (OSSI) released 37 cultivars of 14 crop species under an "open source" Pledge. OSSI is creating a new conduit for releasing plant germplasm with the objective of enlarging, rather than reducing, the "freedom to operate" available to the plant breeding and farming communities. Concerns over the changing intellectual property landscape and especially the increasing difficulties in accessing genetic resources have led to the creation of OSSI by a working group of plant breeders, farmers, nonprofit agencies, seed advocates, and policymakers.

Plant breeding, in its most fundamental form, relies on humandirected selection in genetically variable populations of plants. With the increase in proprietary protection for crop plants, plant breeders' ability to access diverse cultivars and the traits they encompass is becoming more restricted, threatening the exchange of germplasm that underpins the development of new cultivars. OSSI seeks to

Published in Crop Sci. 55:1-8 (2015).

doi: $10.2135 /$ cropsci2014.10.0708

Freely available online through the author-supported open-access option.

(C) Crop Science Society of America | 5585 Guilford Rd., Madison, WI 53711 USA

All rights reserved. No part of this periodical may be reproduced or transmitted in any form or by any means, electronic or mechanical, including photocopying, recording, or any information storage and retrieval system, without permission in writing from the publisher. Permission for printing and for reprinting the material contained herein has been obtained by the publisher. 
maintain open access to plant genetic resources worldwide and to foster innovative plant breeding for the development of productive and resilient cultivars. The first half of this paper will examine the forces that over the past century have led to concerns with the current paradigm for germplasm exchange. The second half of the paper will describe the genesis of OSSI, and what the initiative intends to accomplish. We invite our colleagues to join us in this project.

\section{HISTORICAL FORCES AND TRENDS}

Humans have been practicing plant breeding since the earliest instances of plant domestication. Selection for increased yields, favorable architecture, improved flavor, pest resistance, and adaptation to new environmental conditions has resulted in essentially all of the plant-based foods and fibers utilized today. Food security and the resiliency of our agricultural systems depend on both the diversity among crop species and also the genetic diversity within those species. In particular, it is the within-species genetic diversity that classical plant breeding relies on to drive crop improvement.

While farmers have been practicing plant breeding for centuries, plant breeding as a scientific discipline did not begin until the late 19th and early 20th centuries following the development of repeatable, quantitative approaches such as the progeny test (Goldman, 2000). Recurrent selection for economic traits was first practiced in a scientific context in maize (Zea mays L.) and sugarbeet (Beta vulgaris L.), leading to the subsequent development of selection strategies that were further enhanced with the rediscovery of Mendel's laws in 1900. Early in the 20th century, land-grant universities in the United States established plant breeding programs to develop new crop cultivars for farmers in different parts of the country. Public institutions were the foundation of this new form of applied evolution.

The invention of hybrid corn in the 1920s and the application of biotechnology to crop plants from the $1980 \mathrm{~s}$ to the present have led to increasingly restrictive intellectual property rights legislation and practice. Both biological and legal means for intellectual property protection have been deployed and have together catalyzed significant changes in the seed industry, especially corporate consolidation and the displacement of public institutions by private firms as the dominant actors in crop variety development (Kloppenburg, 2004). Intellectual property legislation passed in the United States and in Europe over the past $80 \mathrm{yr}$, and now being promoted globally, has established and progressively reinforced increased proprietary rights to genetic material and is significantly affecting breeders' and farmers' sharing of and access to germplasm (Price, 1999; Coffman et al., 2003; Graf et al., 2003; Louwaars et al., 2009). This narrowing of breeders' and farmers' freedom to operate threatens the exchange of germplasm, which in turn reduces the within-species diversity available for the development of new cultivars.

Maize provides a paradigmatic example of the historical development of restrictions on access to germplasm. While the genetic features of hybridization initially offered a "biological patent," literal patenting has proliferated in the last 15 yr. Most recently, with the advent of the "bag tag" or the "technology use agreement," contract law is being applied to the control of seed and of its reproductive capacities.

Maize was domesticated from its wild relative, teosinte [Zea mays L. subsp. mexicana (Schrad.) H. H. Iltis], around $9000 \mathrm{yr}$ ago by indigenous peoples of Mesoamerica (Buckler and Stevens, 2005). Teosinte was transformed from a plant that produced 6 to 12 small, hard kernels, into modern maize plants through annual selection by farmers for plants with desired characteristics. These farmers made improvements on maize, with their only reward being the improved traits incorporated into the crop. Today, commercial maize cultivars are generally protected by dozens of patents on specific traits, license agreements, contracts, and trade secrets, allowing developers to own and manage the intellectual property associated with their work. "Bag tag" licenses and associated "technology use/stewardship agreements" for modern maize cultivars specify that users cannot save, replant, use as a parent, or conduct research with the seed. Farmers acquiring such cultivars no longer purchase, but rather license the one-time use of seed (Winston, 2008). Even though the genetic changes brought about by modern plant breeders may be similar in kind to the changes made by plant breeders for millennia, the ownership conferred on their cultivars through modern forms of intellectual property protection are qualitatively new.

While maize provides a vivid example of the trends we have observed over the past century, the forces that propelled the socioeconomic transformation of maize are now driving similar patterns of change in many other commercial crops. Even the exchange of nonelite germplasm among plant breeders, which in the past was relatively unencumbered, is now likely to be governed by a material transfer agreement (MTA) that stipulates conditions for use, including royalty sharing should derivatives be commercialized. Because plant breeding depends on the cyclical process of selection and recombination, restrictions imposed on germplasm through the assertion of intellectual property rights and contractual obligation are restricting germplasm sharing.

Crop germplasm is part natural resource and part human innovation. The interaction of these two spheres has operated productively for thousands of years from the time plants were domesticated and into most of the 20th century. Since the 1970s, however, there has been a marked shift away from the normative perspective that plant germplasm is the common heritage of humankind to the legalistic idea that one can claim ownership over an entire plant's genotype by making even a small modification or addition to an already 
existing cultivar. What gives anyone the right to claim so extensive a degree of ownership and control over a crop that so many generations of humans have contributed to, when our hands have only touched it for a brief time?

\section{BIOLOGICAL AND LEGAL FORMS OF INTELLECTUAL PROPERTY PROTECTION}

The transition from open-pollinated to $F_{1}$ hybrid maize in the first few decades of the 20th century in the United States was fueled by both market-based and biological innovations (Duvick, 2001). The biological insight was the counterintuitive and prolonged inbreeding of individual plants, which weakened them but purged them of deleterious recessive alleles, followed by hybridization to produce a highly heterozygous $F_{1}$ hybrid. This so-called inbredhybrid method described by East (1909) and Shull (1908) became the dominant paradigm for modern crop breeding worldwide by the end of the century, particularly for naturally outcrossing crop species. $F_{1}$ hybrids were highly uniform, vigorous, stable across environments, and generally high yielding, making them valuable for both farmers and seed sellers. The market-based change was that farmers, for the first time, began buying their seed anew each year rather than saving seed from the previous crop and replanting it the following year. The $\mathrm{F}_{1}$ hybrid seed embodied a biological form of intellectual property protection in that it didn't breed true. The inbred-hybrid system enabled exclusivity for seed sellers because inbred parent lines could be protected, essentially functioning as a trade secret.

In the early 20 th century, as nursery and seed businesses began to develop, they faced a fundamental problem: plants are unstable as a commodity form (Kloppenburg, 2004). The fact that plants can reproduce themselves made the commercial exploitation and control of seed difficult without the facilitating effects of intellectual property rights (IPR). The first law to provide any type of legal protection over plant cultivars was the Plant Patent Act of 1930. This law granted a certificate to inventors or discoverers of a new asexually propagated cultivar ("other than a tuber propagated plant") as long as the new cultivar was "distinct and new." The Plant Patent Act was a boon for the nursery industry and those interested in ornamental crops because many of these plants are propagated asexually. It limited the degree to which one could sell a "copycat" cultivar that was developed by simply propagating a competitor's plant material. However, the majority of our food supply is based on the production of annual seed crops, which the Plant Patent Act was not designed to protect.

In 1961, the International Convention for the Protection of New Varieties of Plants introduced a system for the protection of plant germplasm in Europe. This framework specified intellectual property arrangements for the protection of plant germplasm for countries agreeing to become members of the Union for the Protection of New Varieties of Plants (UPOV). The purpose of UPOV protection was to ensure that production of a new plant cultivar for the purposes of commercial sales and marketing required the approval of the plant breeder. The breeder's authorization, however, was not required when using the protected variety as a source of variation when developing subsequent new cultivars. Membership initially focused on nations in Europe and the global North, but has now expanded to 72 nations including many in the global South (Anonymous, 1961).

In the United States of America it was not until the Plant Variety Protection Act (PVPA) of 1970 that new cultivars of sexually reproduced plants could be protected. This act granted a 17-yr, patent-like Plant Variety Protection (PVP) certificate for a new cultivar that was determined to be distinct, uniform, and stable. The PVPA was amended in 1994, changing the term of protection to $25 \mathrm{yr}$ and harmonizing U.S. arrangements with those of UPOV. A PVP certificate gives the owner the right to exclude others from selling or reproducing a cultivar but also carries several important exclusions including a farmer's right to save seed of the cultivar and researchers' right to use a PVP-protected cultivar for further breeding and research. The passage of the PVPA ushered in a new era in the seed industry where investment in breeding of high-acreage crops such as soybean [Glycine max (L.) Merr.], wheat (Triticum aestivum L.), and cotton (Gossypium hirsutum L.) - crops that were not biologically protected by the inbred-hybrid system - could be recovered. The PVPA preceded the acquisition of regional and national seed companies by multinational chemical and pharmaceutical companies between 1970 and 1980 and the beginning of the biotech-seed industry (Charles, 2001).

The 1980s witnessed a number of court cases that solidified the increasingly restrictive IPR trend for protecting plant germplasm. These decisions affected not only the private sector, but the public sector as well. The 1980 U.S. Supreme Court decision in Diamond v. Chakrabarty established the patentability of living organisms. The Ex parte Hibberd decision by the U.S. Board of Patent Appeals and Interferences in 1985 affirmed the eligibility of plants for utility patents. The U.S. Supreme Court upheld this decision in 2001 in the J.E.M. Ag Supply, Inc. v. Pioneer Hi-Bred International, Inc. case.

In 1980, the Bayh-Dole Act allowed recipients of federal funds, such as colleges and universities, to assume ownership of the inventions resulting from federally funded research rather than assigning title to the federal funding agency. This allowed new plant cultivars developed at land-grant universities to be protected and licensed by the university, further changing the relationships of public universities to farmers and the seed industry. Increasingly, private contract law is being used in conjunction with new legislation to further restrict crop genetic resources. This 
includes the use of "bag tag" licenses and MTAs between parties, detailing specific restrictions on seed.

Utility patents have been applied for, and in some cases granted, on specific naturally occurring traits as well as on cultivars. In most cases, one could argue that these do not fit the "novel," "non-obvious," or "no prior art" requirements necessary for a utility patent to be granted in the United States. For example, in 2004 Seminis vegetable seed company was granted U.S. patent 8,030,549 for "Broccoli type adapted for ease of harvest" (Van den Bosch and Boon, 2011). However, more than a third of the parent material includes germplasm developed and used in Oregon State's breeding program as far back as the 1960s, potentially indicating prior art (Hamilton, 2014). The Dutch seed company, Rjik Zwann, was granted a patent on "Red lettuce" described as having "red leaves throughout the head, including the heart" (Moor et al., 2012). Frank Morton, an independent plant breeder and owner of Wild Garden Seed in Oregon, achieved a similar type of lettuce that is red to the core using different material than the Dutch company (Hamilton, 2014), raising the question of how both obviousness and novelty are being evaluated by the U.S. Patent and Trademark Office in relation to plants. Additionally there are U.S. patent applications on "Carrots having increased lycopene content" (Maxwell, 2008), and a "Novel melon plant" (Casanueva et al., 2014) that refers to "melon plants capable of producing fruits with a new pleasant taste."

Unlike a PVP certificate, a utility patent does not allow for breeding, research, or seed saving on a patented cultivar, thus jeopardizing plant breeders' freedom to operate even on their own material. How might plant breeders working on these crops perceive their own freedom to operate given that major traits of interest have now been patented? While some may continue their breeding efforts, no doubt others will find this level of patent protection to have a chilling effect on their breeding programs.

Ironically, the U.S. patent system was established to promote the exchange of ideas surrounding particular technologies. By sharing the details of how an invention was conceived and reduced to practice, an inventor would be granted a monopoly on the use of that invention for a period of $20 \mathrm{yr}$. However, studies in recent years have raised questions about whether the patent system does in fact achieve this objective (Marshall, 2013). Particularly in the areas of genetics, computer science, and engineering, patenting seems to have the potential to reduce innovation by limiting access to data and biomaterials that might otherwise stimulate more inventions. As a way to keep genetic information in the public domain, some biomedical researchers have been contributing data on human gene variation to a public database called ClinVar, which is managed by the National Institutes of Health's National Center for Biotechnology Information. This database may, in future years, limit the patentability of new genetic variants by publishing their sequence information (Marshall, 2013).

The trajectory described above outlines the trend of IPR for plants. Intellectual property rights are "a complex mix of different interests that either protects an intellectual creation by an exclusive and proprietary right or guarantees some free access to, and use of, an intellectual creation" (Dusollier, 2007). Over the past $100 \mathrm{yr}$, there have been an increasing number of ways to protect plant germplasm, incrementally creating more exclusive and proprietary rights over plant material. While some advocates of a strong IPR regime argue that more powerful IPR laws lead to higher levels of investment and innovation, there is little empirical evidence to support this (Stiglitz, 2014). In such a consolidated industry, there are high barriers to entry and there is little room for new companies to be competitive, or even have access to elite material to start a new breeding program. Universities and other research institutions are also restricting use of germplasm through patents, licenses, and MTAs.

This system has led to a reduction in the free exchange of germplasm, and in some cases proprietary material cannot be used for research or breeding purposes. With the dramatic consolidation in the seed industry and the IPR regime placing restrictions for use on plant germplasm, a plant breeder's ability to make gain from selection and farmers' sovereignty over seed have been substantially affected.

\section{SOURCES OF GERMPLASM FOR BREEDING}

Increasingly restrictive IPR over the past century have made obtaining new germplasm, whether from other plant breeders or public repositories in other countries cumbersome at best, and at times impossible. The complex web of MTAs, licenses, contracts, patents, and phytosanitary restrictions that follow plant germplasm today have the potential to greatly inhibit exchange of material among plant breeders and farmers around the world. To develop a competitive plant breeding program from scratch today, especially in a crop like maize, would be nearly impossible.

Although the U.S. National Plant Germplasm System (NPGS) remains one of the few germplasm repositories in the world where crop germplasm is freely available without restriction, at least two important limitations render this resource an unlikely permanent source for initiating new breeding activities. First, because all germplasm in the NPGS is freely available, it does not contain large reserves of elite crop germplasm. Most elite material is now proprietary and unavailable for open distribution, though some germplasm accessions held by NPGS are cultivars that are no longer protected by intellectual property rights and have become publicly available. Second, the NPGS functions like a commons in that all materials are available without restriction. Thus, it is possible to extract material from this source and, through breeding activity and intellectual 
property protections such as patents, render derivatives unavailable to others. The same could be said for other commons-based germplasm repositories, which do a great service by making germplasm available to gardeners, farmers, and breeders but - ironically-may also foster limitations on germplasm access over the long term. Addressing this paradox is at the heart of OSSI.

Plant breeders in both the public and private sectors who work on the same crops have long exchanged germplasm freely. Historically, there has been a loose, ethical framework-occasionally formalized as in the Wheat Workers Code of Ethics (Quick, 1993; National Wheat Improvement Committee, 1994) - between breeders that discouraged directly appropriating someone else's material and instead encouraged exchange. The Plant Patent Act and PVPA, as well as PVPA-like legislation enacted by other UPOV members, allow for material protected with a plant patent or certificate to be used for breeding without first seeking approval of the original breeder, and with the express purpose of allowing the best materials to be combined by others. However, new varieties derived from these subsequent breeding efforts may themselves be patented or protected through contract law mechanisms so that the selection-recombination cycle of plant breeding, and the tradition of germplasm sharing, are interrupted. Now, obtaining material from both private companies and public institutions generally comes with a complex legal contract outlining how material can be used and who has claims to any resulting commercializable outcomes.

\section{THE OPEN SOURCE SEED INITIATIVE}

Over the past $100 \mathrm{yr}$, we have experienced a dramatic transition in how plant germplasm is distributed, developed, and released, from a freely available resource primarily located in the public sector to proprietary structures managed largely by the private sector. In response to this transition, OSSI (www.osseeds.org [accessed 26 Feb. 2015]) was developed by a group of plant breeders, farmers, seed companies, nonprofit organizations, and policymakers with the goal of promoting and maintaining open access to plant genetic resources worldwide. OSSI seeks to provide an alternative to pervasive IPR agreements that restrict freedom to use plant germplasm through the development and promulgation of a Pledge which is intended both to raise awareness of these issues and to ensure that germplasm can be freely exchanged now and into the future.

The idea for creation of an open source system for plant germplasm is not unique to OSSI's current effort (see Aoki, 2009; Bragdon, 2005; Jefferson, 2006; Kloppenburg, 2010; Srinivas, 2006). Indeed, plant breeder Thomas Michaels first proposed such an arrangement in 1999 at the Bean Improvement Cooperative Conference (Michaels, 2000). His comments in that paper are a succinct and accurate summary of the perspective that still undergirds and motivates OSSI: "the opportunity to obtain more exclusive novel gene sequence and germplasm ownership and protection, the mindset of the public sector plant breeding community has become increasingly proprietary. This proprietary atmosphere is hostile to cooperation and free exchange of germplasm, and may hinder public sector crop improvement efforts in the future by limiting information and germplasm flow. A new type of germplasm exchange mechanism is needed to promote the continued free exchange of ideas and germplasm. Such a mechanism would allow the public sector to continue its work to enhance the base genotype of economically important plant species without fear that these improvements, done in the spirit of the public good, will be appropriated as part of another's proprietary germplasm and excluded from unrestricted use in other breeding programs" (Michaels, 2000).

The specific mechanism Michaels proposed was a "General Public License for Plant Germplasm" that was explicitly modeled on the "GNU General Public License" developed and deployed under the auspices of the Free Software Foundation (Stallman, 2002).

The success of the free and open source software (FOSS) movement has been a key inspiration for OSSI and appeared to present a plausible alternative to the conventional IPR regime. Notably, the legal tool that engenders this plausibility is a license, which is an expression of contract law (not IPR law). FOSS is copyrighted and then made available under a license that permits further modification and distribution as long as the modified software is distributed under the same license. This arrangement produces a "viral" effect that, critically, enforces continued sharing as the program and any derivatives and modifications are disseminated. Also critically, the virality of the license prevents appropriation by companies that would make modifications for proprietary purposes since any software building on the licensed code is required by the license to be openly accessible. This feature-called "copyleft"-is what distinguishes "open source" from mere "open innovation." Thus, software developed under an open source license is released not into an open innovation/open access commons, but into a "protected commons" populated by those who agree to share but effectively inaccessible to those who will not.

In April 2010, a small meeting was held in Madison, WI, to explore the prospects for implementing some sort of open source initiative for seeds. Enthusiasm for the idea led to targeted recruitment for attendance at a second meeting held in May 2011 in Minneapolis, MN. Participation was expanded to include additional public breeders, farmers, indigenous groups from both global North and South, an organic seed company, and several nonprofit advocacy organizations. Those attending the Minneapolis meeting constituted themselves as 
the "Open Source Seed Initiative," discussed principles and objectives, and outlined a course of action. The priority task was determined to be creation of a legally defensible, open source license for plant germplasm (Kloppenburg, 2013).

However, a sustainable and enforceable mechanism for an open source system for plant germplasm proved difficult to develop. OSSI's attorneys could — and, indeed, did — draft a legally defensible, "copyleft" license that would ensure that OSSI-licensed seeds and their derivatives would, by legal mandate, remain freely available for use. However, the eight-page license that resulted was densely packed with legal terminology. Further, since a license is a private contract which prospective licensees must have an opportunity to read its entirety, the complete language of the license would have to appear on every package or container of seed sold or exchanged. The probability that such a license would be transmitted with the seed for more than a few exchanges is very low, and the consequent failure to virally propagate would negate the key and most powerful feature of the open source license approach. Additionally, while software code is protected by copyright, plant cultivars do not have copyright to back up a "copyleft" or open source license.

After nearly 2 yr of trying to overcome these obstacles, OSSI decided to shift its efforts to a different plane. Abandoning the cumbersome legal approach, OSSI chose instead to base its efforts on the ethical plane and to build on the obligation that many breeders have historically felt to freely share their work in the public interest. In place of a license, OSSI has crafted a Pledge that reads:

"You have the freedom to use these OSSI seeds in any way you choose. In return, you pledge not to restrict others' use of these seeds or their derivatives by patents, licenses or other means, and to include this Pledge with any transfer of these seeds or their derivatives."

With this Pledge, OSSI appeals to the ethical and social norms that link plant breeders, seed companies, farmers, gardeners, and eaters. The Pledge represents a call to revitalize a system of practices characterized by germplasm exchange unencumbered by complex legal agreements. The Pledge is meant to recognize and honor the historic and collective contributions of farmers and plant breeders to the generation and maintenance of the existing pool of crop genetic material.

Cultivars released under the Pledge function both as entities that can be planted and consumed as well as vectors for the genes they contain. Over time, these freely available materials will help to maintain access to the diversity of alleles contained in an open source repository within which plant breeders continue to have maximum "freedom to operate." The OSSI Pledge will function analogously to an open source software license, although it is likely not legally enforceable. The Pledge is intended to foster unfettered exchange of germplasm and freedom to use the material for any purpose, with the single proviso that by accepting the Pledge the user commits to allowing others freedom to use the material or derivatives of the material in further plant breeding or seed saving. While the Pledge is simple in structure, it is very complex in concept. A number of words require elaboration, including "freedom," "acknowledgement," "reward," "restrictions," and "transfer."

On the basis of the Pledge, OSSI-designated seed is considered to be "free seed" or, alternatively and more accurately, "freed seed." That is, it is free for any use, though not necessarily free of cost. The FOSS advocate Richard Stallman has famously proposed that FOSS code is " "free' as in 'free speech,' not as in 'free beer"' (Stallman, 2002). Under the auspices of open source, it is imperative that the word "free" is understood to connote freedom and not price. Free and open source software code is not necessarily given away free, it can be sold. Nor does free software have to be given to anyone who asks. Similarly, OSSI seed can be sold, and it can be sold exclusively to a single recipient. The OSSI-designated seed need not be provided to anyone who asks for it. The purpose of the Pledge, and the basis of the concept of "freed seed" as OSSI defines it, is that "freed seed" has been freed from restrictions on the uses to which the seed can be put by those to whom it is transferred, by sale or without charge, under the OSSI Pledge.

OSSI is committed to recognizing and rewarding the labor that goes into developing new and useful arrangements of plant genes. The "free rider" issue-unrecompensed appropriation and multiplication for sale of a new variety by an unauthorized party-is indeed a legitimate concern. Thus, OSSI does not consider agreements between an originator of a novel cultivar and a commercial multiplier, which specify a sharing of benefits, to be a restriction. The sharing of financial benefits is consistent with OSSI's goal of supporting, acknowledging, and rewarding plant breeding efforts. A farmer or breeder could, for example, contract with a seed producer to multiply seed of an open source variety and both parties could share in the revenue generated from the commercial sale of those open source seeds. That said, the OSSI Pledge does not countenance agreements that alienate rights to control the uses to which a novel variety or its derivatives can be put. Nor can farmers or breeders be prohibited from multiplying and using the seed on their own farms or in their breeding programs.

It is important to emphasize that under the OSSI Pledge the user is committing "not to restrict others' use of these seeds and their derivatives..." Therefore, the Pledge is a commitment by recipients of OSSI seed that any unique, derivative germplasm they subsequently develop by breeding with OSSI material will not have restrictions imposed on its uses by anyone to whom it is transferred. It is our expectation that breeders who release cultivars that incorporate OSSI parentage will in turn register these cultivars with OSSI. This virality is what distinguishes the "protected commons" 
created by acknowledging the OSSI Pledge from the "public domain." While material in the public domain can be utilized by anyone, derivatives of that material can be protected and restricted from further use. OSSI considers restrictions to be any type of public patent or private contract law that prevents others from being able to use material for breeding, research, or seed saving. This does not necessarily include a contract that a breeder might sign with a seed company to establish a benefit sharing agreement. Nor does it prevent an agreement between a seed company and a seed grower to increase seed for sale. OSSI's mission is to create a social contract between participants that encourages exchange and sharing, rather than restriction. It is OSSI's intention that when transfer of OSSI-designated seed occurs, it will be accompanied by the OSSI Pledge. OSSI's intent is that future generations of open source cultivars and any cultivars derived or selected from open source cultivars continue to be designated as such.

To some it might appear that OSSI's initiative is intended to impede the development of transgenic lines. This is not the case. OSSI's concern is with the social arrangements through which new crop varieties are made available, not the means by which they are developed. A breeder of a novel transgenic cultivar could release the line under an open source arrangement as long as no restriction was placed on its use. Similarly, open source lines could be combined with nonpatented transgenic material, but the progeny of that cross would be recognized as open source and could not be use-restricted. Given the nature of the institutions developing transgenics and their deep commitment to various modes of use-restriction, it is unlikely that any transgenic material will be released under the OSSI Pledge. Conversely, the OSSI Pledge represents an opportunity for breeders with nonconventional goals - organic breeders, for example - to create an independent pool of germplasm that would not be appropriated for protection under intellectual property arrangements.

Two of OSSI's near-term goals are a catalog of open source cultivars and a process for submitting and registering those cultivars. OSSI is not, and will not be, a seed company. It will not be the primary source for maintaining, providing, or selling OSSI-designated seed. Rather, OSSI is a designation that a breeder can choose to use when sharing seed with others that signifies a set of values associated with that seed.

It was, of course, difficult to assess whether there would be interest among breeders in releasing material under so novel and unusual an arrangement as the OSSI Pledge. Rather than speculate, OSSI felt that taking action would provide a useful indication of the plausibility of pursuing the Pledge strategy. We therefore asked the breeders and farmer breeders who have been part of OSSI to commit to releasing material under the OSSI Pledge. In solidarity with La Via Campesina's designation of 17 Apr. 2014 as the International
Table 1. Plant breeders and the crops and cultivar names they released under the Open Source Seed Initiative Pledge on 17 Apr. 2014.

\begin{tabular}{|c|c|}
\hline $\begin{array}{l}\text { Breeder and } \\
\text { affiliation }\end{array}$ & Crop and cultivar name \\
\hline $\begin{array}{l}\text { Patrick Hayes, Oregon } \\
\text { State University }\end{array}$ & Barley, Hordeum vulgare L._-Full Pint \\
\hline $\begin{array}{l}\text { High Mowing Organic } \\
\text { Seed Company }\end{array}$ & $\begin{array}{l}\text { Zucchini, Cucurbita pepo L.-Midnight } \\
\text { Lightning }\end{array}$ \\
\hline $\begin{array}{l}\text { Irwin Goldman, University } \\
\text { of Wisconsin-Madison }\end{array}$ & Carrot, Daucus carota L.-Oranje, Sovereign \\
\hline $\begin{array}{l}\text { Frank Morton, } \\
\text { Wild Garden Seed }\end{array}$ & $\begin{array}{l}\text { Calendula, Calendula officinalis L._Flashback } \\
\text { Mix, Orange Sherbet, Lemon Pastel } \\
\text { Celery, Apium graveolens L.-Redventure } \\
\text { Cress, Lepidium sativum L.-Wrinkled } \\
\text { Crinkled Crumpled } \\
\text { Siberian kale, Brassica napus L.-Red Ursa, } \\
\text { White Russian, Wild Garden Mix } \\
\text { Lettuce, Lactuca sativa L.-Outredgeous, } \\
\text { Joker, Hyper Red Rumple Waved, Merlox } \\
\text { Red Oak, Chartreuse Butter Tongue, Flashy } \\
\text { Lightning Butter-Oak, Blushed Butter Cos } \\
\text { Mustard (mild), Brassica rapa L.-Mizspoona, } \\
\text { Pink Lettucy, Purple Rapa Pop Mix } \\
\text { Mustard (pungent), Brassica juncea (L.) } \\
\text { Czern.-Dragon's Tongue, Magma } \\
\text { Pepper (sweet), Capsicum annuum L.- } \\
\text { Gatherer's Gold Italian, Stocky Red Roaster, } \\
\text { Little Bells } \\
\text { Quinoa, Chenopodium quinoa Willd.- } \\
\text { Brightest Brilliant Rainbow, Cherry Vanilla, } \\
\text { Red Head } \\
\text { Winter Squash, Cucurbita pepo-Delicata } \\
\text { Zeppelin }\end{array}$ \\
\hline
\end{tabular}

Kevin Murphy and Stephen Jones, Washington State University

Jonathan Spero, Lupine Knoll Farm

Broccoli, Brassica oleracea-Solstice Siberian kale, Brassica napus-Siber Frill

Day of Struggle in Defense of Peasants' and Farmers' Seeds, OSSI chose that date as the target for its first release. We were gratified to have seven breeders from public universities, seed companies, and farms commit to releasing $37 \mathrm{cul}-$ tivars of 14 crop species under the OSSI Pledge (Table 1).

There has been substantial interest in the United States and internationally in what OSSI is undertaking (e.g., Charles, 2014; Hamilton, 2014; Shemkus, 2014). Further, the demand for, and willingness to pay for, OSSI seed was unexpected and substantial. This demand is likely not principally related to the agronomic characteristics of the seed, but to its sociopolitical context. It would appear that there is very considerable potential for supplying a market for "free seed" that is analogous to the market for "fair trade." The implication is that carrying "free" seed in a commercial seed catalog could be an attractive niche for smaller seed companies. This proposition is already being tested by High Mowing Organic Seeds and by Wild Garden Seeds. While OSSI is currently focusing on working within the U.S. context, OSSI is engaging interested collaborators around the world to develop an international network. 


\section{INVITATION TO PARTICIPATE}

OSSI invites interested plant breeders and farmers to contribute novel cultivars or populations to this initiative. Please see www.osseeds.org.

\section{CONCLUSION}

Plant breeding has its origins in antiquity with the domestication of crops, some 10,000 yr ago. Ninety-nine percent of the period since domestication has been characterized by germplasm sharing, while the remaining $1 \%$ has been associated with the control of germplasm and the intellectual property associated with cultivar development. Developments in biotechnology and the expansion of legal protections afforded to seed have hastened this change. Because plant breeding depends to a great extent on the introduction of genetic diversity to breeding programs, increasing the legal and physical control over germplasm bodes poorly for the future of our crops. OSSI offers an alternative conduit for germplasm that fosters free exchange and seeks to limit restrictions that would otherwise keep these seeds from being grown, bred, traded, and sold. Theodore Roosevelt, former U.S. president, said, "It is not what we have that will make us a great nation; it is the way in which we use it." Germplasm is a resource that we have, but we must use it in a way that protects it from being entirely privatized and sequestered from the common good.

\section{References}

Anonymous. 1961. Act of 1961 International Convention for the Protection of New Varieties of Plants. UPOV. www.upov.int/ export/sites/upov/upovlex/en/conventions/1961/pdf/act1961.pdf (accessed 10 Sept. 2014).

Aoki, K. 2009. Seeds of dispute: Intellectual property rights and agricultural biodiversity. Golden Gate Univ. Environ. Law J. 3:79-160.

Bragdon, S. 2005. Open source mechanisms: The example of BIOS. In: N. Louwaars, editor, Genetic Resources Policies and the Generation Challenge Programme, Wageningen, Netherlands.

Buckler, E.S., and N.M. Stevens. 2005. Maize origins, domestication, and selection. In: T.J. Motley et al., editors, Darwin's harvest. Columbia Univ. Press, New York. p. 67-90.

Casanueva, J.I.A., B. Foncelle, J.L.M.E. Nicolet, J.E. Van Doorn, and M.O. Seros. 2014. Melon plants. U.S. Patent No. 8,829,265. Publication date: 9 September.

Charles, D. 2001. Lords of the harvest: Biotech, big money and the future of food. Perseus Publ., Cambridge, MA.

Charles, D. 2014. Plant breeders release first open source seeds. National Public Radio, April 17. www.npr.org/blogs/thesalt/2014/04/17/303772556/plant-breeders-release-first-opensource-seeds (accessed 19 Feb. 2015).

Coffman, W.R., W.H. Lesser, and S.R. McCouch. 2003. Commercialization and the scientific research process: The example of plant breeding. In: P.E. Stephan and R.G. Ehrenburg, editors, Science and the university. Univ. of Wisconsin Press, Madison.

Dusollier, S. 2007. Sharing access to intellectual property through private ordering. Chicago-Kent Law Rev. 82:1391-1435.

Duvick, D. 2001. Biotechnology in the 1930s: The development of hybrid maize. Nat. Rev. Genet. 2:69-74. doi:10.1038/35047587
East, E.M. 1909. The distinction between development and heredity in inbreeding. Am. Nat. 43:173-181. doi:10.1086/279042

Goldman, I.L. 2000. Prediction in plant breeding. Plant Breed. Rev. 19:15-40.

Graf, G., S. Cullen, K. Bradford, D. Zilberman, and A.B. Bennet. 2003. The public-private structure of intellectual property ownership in agricultural biotechnology. Nat. Biotechnol. 21:989-995. doi:10.1038/nbt0903-989

Hamilton, L. 2014. Linux for lettuce. Virginia Q. Rev. 90(3). http:// www.vqronline.org/reporting-articles/2014/05/linux-lettuce (accessed 9 Mar. 2015).

Jefferson, R. 2006. Science as social enterprise: The CAMBIA BiOS initiative. Innovations 1:11-42.

Kloppenburg, J. 2004. First the seed: The political economy of plant biotechnology, 1492-2000. Reissued with a new preface and an additional final chapter, 'Still the Seed.' Univ. of Wisconsin Press, Madison.

Kloppenburg, J. 2010. Impeding dispossession, enabling repossession: Biological open source and the recovery of seed sovereignty. J. Agrar. Change 10:367-388. doi:10.1111/j.1471-0366.2010.00275.x

Kloppenburg, J. 2013. Re-purposing the master's tools. In: Food sovereignty: A critical dialogue, International Conference, Yale Univ., New Haven, CT. 14-15 Sept. 2013.

Louwaars, N., H. Dons, G. Van Overwalle, H. Raven, A. Arundel, D. Eaton, and A. Nelis. 2009. Breeding business: The future of plant breeding in the light of developments in patent rights and plant breeder's rights. Cent. for Genet. Resources Rep., Wageningen, Netherlands.

Marshall, E. 2013. Lock up the genome, lock down research. Science 342:72-73. doi:10.1126/science.342.6154.72

Maxwell, R. 2008. Carrots having increased lycopene content. U.S. Patent Application 20080098493. Publication date: 24 April.

Michaels, T.E. 2000. Should we consider general public license for bean germplasm. Rep. of the Bean Improv. Coop. 43:45. http://naldc.nal. usda.gov/download/IND22077092/PDF (accessed 19 Aug. 2014).

Moor, C.M., E. Carolus, J. Smits, A.M.J. Ammerlaan, J.W. Schut, and K. Reinik. 2012. Red lettuce. U.S. Patent 8,143,487. Date issued: 27 March.

National Wheat Improvement Committee. 1994. Wheat worker's code of ethics. Annu. Wheat Newsl. 49:5 November.

Price, S.C. 1999. Public and private plant breeding. Nat. Biotechnol. 17:938. doi:10.1038/13594

Quick, J.S., editor. 1993. Wheat workers code of ethics. Annu. Wheat Newsl. 39:1 June. p. 24.

Shemkus, S. 2014. Fighting the seed monopoly: 'We want to make free seed a sort of meme.' The Guardian, May 2. www.theguardian. $\mathrm{com} /$ sustainable-business/seed-monopoly-free-seeds-farm-monsanto-dupont (accessed 27 Feb. 2015).

Shull, G.H. 1908. The composition of a field of maize. Am. Breeders Assoc. Rep. 4:296-301.

Srinivas, K.R. 2006. Intellectual property rights and bio commons: Open source and beyond. Int. Soc. Sci. J. 58:319-334. doi:10.1111/ j.1468-2451.2006.00621.x

Stallman, R.M. 2002. Freee software, free society: Selected essays of Richard M. Stallman. SoHo Books, Boston.

Stiglitz, J.E. 2014. Intellectual property rights, the pool of knowledge, and innovation. NBER Working Pap. 20014. Natl. Bur. of Econ. Res., Cambridge, MA.

Van den Bosch, F., and M.P. Boon. 2011. Broccoli type adapted for ease of harvest. U.S. Patent 8,030,549. Date issued: 4 October.

Winston, E. 2008. What if seeds were not patentable? Michigan State Law Rev. 2008:321-344. 